\title{
The Role of Internal Audit as a Starting Point for the Discovery of Irregularities in the Financial Statements of Public Companies in Kosovo
}

\author{
Prof. Asoc. Dr. Hysen Ismajli \\ University of Prishtina, Faculty of Economics \\ Prof. Ass. Dr. Muhamet Aliu \\ University if Prishtina, Faculty of Economics \\ MSc, PhD Cand. Arben SAhiti \\ Teaching Asistnat, University "Kadri Zeka" Gjilan, Faculty of Economics \\ MSc, PhD Cand. Lumbardha Lutolli \\ University of Prishtina, Faculty of Economics
}

\begin{abstract}
The main purpose of this paper is to verify whether the internal audit affects the detection of anomalies and fraud in the financial statements of public companies in Kosovo. To achieve this purpose, we have prepared a questionnaire and distributed to public enterprises in the Republic of Kosovo. The questionnaire includes open and closed questions in the form of Likert scale established to asess proposition and oposition of the participants. Responses were analyzed through SPSS software, and hypotheses were tested by analyzing the correlation. Based on results we can conclude that the role of internal audit can serve as a starting point in finding fraud and errors in financial reports.
\end{abstract}

Keywords: Internal audit, fraud, public companies, performance, standards

\section{Introduction}

The role of auditors is considered to be vital for the proper functioning of financial management in terms of public and private companies, particularly important is their role to find and disclose irregularities in financial statements. The importance and influence of auditors is more prominent in developed countries compared with those in progress. Findings and recommendations are taken into consideration with spetial attention and competent authority undetake further action if irregularities are identified. Public companies in Kosovo, after the war, constantly faced mismanagement on managerial and financial level. Auditor's examinations indicate violations and irregularities that accompany public companies in their daily operation. These irregularities have not only caused considerable financial loss, but also damaged their reputation, and ultimately contributed to the loss of investor's confidence on their potential.

\section{The Purpose of the Research}

Frauds related to the financial statements in most cases begin as minor intelegently manipulative actions non-significant in amount and size aiming to improve results and performance. Consequently, to maintain the status, trickery and deception in these financial statements continue on and grow in size, and the manipulators lose reason and objectivity and end up in a big fraud. In recent decades, we have witnessed a considerable number of cases where private and public companies in the world have experienced fraud in financial reporting, causing turmoil in financial markets, contributing to the loss of share value, loss of investor's confidence and in some cases to their bankruptcy. These scandals have collapses public credibility and legitimacy of the institutions where the fraud occurred (Snider, 2000). Attention to fraudulent activities related with the preparation and filing of corporate financial statements has increased considerable in the aftermath of the Enron scandal in the US. This scandal has left un-imaginable consequences in the financial world and has had a significant impact on the supervision policies to avoid potential scams that may hit the market from time to time. In this context, the purpose of this 
paper is to assess the role of internal audit as a starting point for the discovery of irregularities in the financial statements of public companies in Kosovo.

\section{Literature Review}

\section{The Role of Internal Audit}

In recent decades, the role of internal auditors has continually evolved to adapt to changes in international accounting standards (IAS), growing competition, and objectives of the boards of public and private companies. These changes are associated with implications and they have raised questions but also concerns about the role of internal auditors and their objective and indipendend function.

The issue often raised by researchers and requiring fair treatment is whether the internal auditors have a primary role of consulting, of providing objective opinions to the management or providing solutions that they believe are in the best interest of companies where they are employed. According to the study of Brady and Lowe (2003), internal auditors tend to serve more in a position that is in the interest of employers.

The scope of internal auditors is very professional and requires constant vigilance to meet their objectives. The level of professionalism of internal auditors may not be the same and useful for all types of businesses because of the different nature of the business activities of the companies. Therefore, it is imperative for companies to employ auditors who not only have knowledge regarding the internal audit but also the business industry in which they operate in order to get the best of results and to contribute positively to the welfare of the company (Agarwal and Medury, 2014).

According to Epstein and Geiger (1994) the management and investors expect from internal auditors to contribute more, with their reports as a starting point for the discovery of irregularities in financial statements, but there is a gap between the expectations of investors and the actual performance of the inernal auditors. To avoid this defect and to enhance the independence of internal auditors, researchers of internal audit have concluded to change the concept and the method of auditor's selection. They argue such appointments to be made by external actors in order to increase efficiency in terms of detection of irregularities in the financial statements (Agarwal and Medury, 2014).

The relationship between the audit committee, auditor's independence and internal control weaknesses

Zhou et al. (2007) suggests that there is a relationship between the quality of the audit committee, auditor's independence, and internal control weaknesses. Firms are more likely to be associated with internal control weaknesses, if their audit committees have fewer financial expertise or, more accurately have less financial accounting expertise and financial expertise of non-accounting. Alternatively, they are also more likely to identify internal control weaknesses, if auditors are more independent in their work.

Besides firms that have high turnover of auditors are more likely to have more advanced internal control weaknesses (Zhou et al. 2007). In addition, according to Schwartz firms that are in financial distress are more likely to change auditors than those that are financially healthy and therefore highlight further the internal control weaknesses.

Study of auditor's responsibility about the discovery of Barbados fraud

One factor that was evident from the data collected was that educational background in accounting affects the knowledge and perception that auditor should detect fraud. Most of the respondents with an accounting background, knowledge or training have expressed the opinion that auditors were responsible for detecting fraud. This included some auditors and responsible management who had knowledge of accounting. However, users who do not have knowledge of accounting differed on their opinion (Alleyne and Howard, 2005). Based on their experience as reasons for committing fraud, respondents suggested the following factors: (1) the moral values of individuals; (2) the need to maintain the growth of their social status, (3) dissatisfaction with their work; (4) individuals with drugs issue and gambling addiction; (5) individuals with debt growth trend; (6) individuals "see other people doing it"; and (7) individuals who think they will not be caught.

\section{Research Methodology}

This paper is processed using primary data, because it best suits the nature and scope of this paper. The primary data used during analysis were obtained by questionnaire from public companies in Kosovo, and are used to test the hypothesis raised. Results of the questionnaire are quantified through the use of SPSS software package. According to McCullough 
(2004), it is a quantitative research and experimental statistical analysis that can validate a new concept or idea that researchers want to address. The methodology used allows the analysis to be more scientific and more objective compared with other forms of research (Lomas, 2011).

\section{Questionnaire Design}

The questionnaire in the survey consists of 30 questions, divided into four parts:

The first part of the questionnaire contains questions about the characteristics of respondents

The second part contains questions regarding the procedures to be taken by the auditor to recognize and understand the entity and its environment

The third section contains questions related to: Internal Audit Function in public companies in Kosovo

The fourth section contains questions related to: the role of internal audit as a starting point for the discovery of irregularities in financial statements.

The questionnaire includes opened and closed questions in the form of a Likert scale in order to examine how participants agree or disagree, and to avoid detours which can lead to misunderstandings. This form of the questionnaire can be transferred easy in digital design which is suitable for statistical analysis.

\section{Hypothesis: Statements}

Hypotheses are assumptions made on the basis of limited evidence that serve as a starting point for further investigation of phenomena that we intended to treat. A statement have two hypotheses that explain the relationship variables $(\mathrm{H} 0)$ that declares that there is no relationship between two variables and alternative hypothesis $(\mathrm{H} 1)$ that declares that there is a relationship between two variables (Sekaran, 2003). In this research we have presented hypotheses listed below to assess whether the role of the audit serves as a starting point for the discovery of irregularities in the financial statements of public companies in Kosovo

$\mathrm{H} 1$ : The role of internal audit does not affect the increase on the reliability of reporting of financial statements;

H01: The role of internal audit affects the increase of reliability of reporting of financial statements

$\mathrm{H} 2$ : The role of internal audit does not serve as the starting point in finding irregularities in the financial statements.

H02: The role of internal audit does serve as the starting point in finding irregularities in the financial statements.

\section{Characteristics of respondents}

The research included 10 public companies from a total of 30 that are currently publicly owned and the response rate of 33. 3\% is achieved. Questionnaire were codified and responses are imported in research methods of the social sciences (SPSS).

\section{Analysis}

Section A: Based on the data 70\% of respondents are economics graduates and $30 \%$ have master level. Out of these professionally qualified as Certified Accountant are $40 \%$, licensed auditors are $30 \%, 10 \%$ technical accountants, while $20 \%$ no academic background. Out of these $50 \%$ of respondends are auditors and heads of internal audit, $50 \%$ of respondents had experience 5 to 10 years, $40 \%$ with less than 5 years and $10 \%$ with over 15 years experience in auditing.

Section B: Procedures that internal auditor should undertake to recognize and understand the entity and its environment.

By analyzing the responses of the second section regarding with procedures that the auditor should undertake to know and understand the entity and its environment we have reached the following conclusions: $50 \%$ of respondents completely agreed that the auditor should question management, supervisory personnel, or any customer who has knowledge of the event, and that the knowledge is obtained during the conduct of the proceedings. Also, $50 \%$ agreed that auditors should have communications with the previous auditors including reviewing the work papers of auditors. One of the procedures that internal auditor must undertake is receiving annual reports or interim reports to shareholders, with which fully agreed 
$60 \%$ of respondents. While $60 \%$ agreed that business plans, strategic plans or other related documents should be review. It should be emphasized that $50 \%$ of respondents agreed completely that the auditor should know the latest developments and industry trends, and to consider the effects of the latest regulations and accounting guidelines.

Section C: The function of internal audit in public companies in Kosovo

According to respondents in the third section we reached the following conclusions. The results show that $70 \%$ of respondents agree that internal audit through consulting and auditing services enables the company to better achieve their objective, 50\% agreed completely (and agreed) that the internal audit influences the reliability of financial reports, and $50 \%$ agreed that internal audit affects the preservation of assets of the company and that their role is in compliance with laws and regulations. It should be noted that $70 \%$ stated that the role of internal audit leads to improved risk management, $60 \%$ agreed that it affects the improvement of internal control, and 50\% stated that they agree that the role of internal audit impacts and improves governance processes.

Section D: The role of internal audit as a starting point for the discovery of irregularities in the financial statements

In the fourth section the results show that: $70 \%$ agreed that auditor's skepticism influences the auditor's opinion on the financial statements, while $50 \%$ agreed completely that segregation of tasks and duties reduces the possibility of the appearance of fraud, and 50\% stated that they agree that errors and fraud affect the fair reporting of financial statements. In addition, $40 \%$ fully agreed and $40 \%$ agreed that derogation or misrepresentation fact is fraud, while $50 \%$ stated that they agree that errors in estimates or bank notes are fraudulent. Furthemore, $80 \%$ said they agree that recommendations arising from the reports of the internal audit are implemented in the reporting of public companies, while $60 \%$ agree that the majority of fraud and error reporting remains reported only within the institution, as $50 \%$ agreed completely that reporting fraud and errors should be based on sufficient evidence demonstrating that fraud or error has been committed, $40 \%$ of respondents were neutral that auditors who make up the team of detecting and reporting fraud and error in financial statements should have good forensic analysis skills. They stated that $70 \%$ agree that the role of internal audit serves as a starting point for the discovery of irregularities in the financial statements as well as $60 \%$ strongly agree that the quality of internal audit affects the detection of fraud and misstatement in the financial statements of public enterprises in Kosovo.

\section{Correlation Analysis}

Correlation is a measure of the relatedness between two variables (Armitage and Colton, 1999). It has a wide application in economics, business and social sciences in general. The correlation coefficient provides a mathematical value to measure the power of linear interconnection between the two variables. The first hypothesis is formed by the survey which seeks to test whether the role of the internal auditor does not affect the establishment of fair financial statements (independent variable), which is associated with procedures that should be undertaken (the dependent variable). To prove this hypothesis, we used the correlation coefficient by the SPS software.

$\mathrm{H} 1$ and $\mathrm{H} 01$ Hypothesis:

$\mathrm{H} 1$ : The role of internal audit does not affect the increase on the reliability of reporting of financial statements; 
H01: The role of internal audit affects the increase of reliability of reporting of financial statements

\section{Correlations results}

\begin{tabular}{|ll|l|l|}
\hline & Processes & Results \\
\hline RIA & 1 & $.925^{\star *}$ \\
& Pearson Correlation & & 003 \\
& Sig. (2-tailed) & 10 & 10 \\
\hline N & Pearson Correlation & 1 \\
& Sig. (2-tailed) & $925^{\star \star}$ & \\
& N & .003 & 10 \\
\hline
\end{tabular}

${ }^{* *}$. Correlation is significant at the 0.01 level (2-tailed).

RIA - the role of internal audit

PIA - procedures that should be undertaken by internal audit

Table 5 shows the results of the correlation. The value of the correlation coefficient is $0.925 r s=0.003$ and $p$-value was < 0.05 which show that they have a strong positive relationship. $\mathrm{H} 1$ hypothesis is not accepted but the alternative hypothesis $\mathrm{H} 01$ is accepted indicating that the role of the internal auditor's affects the reliability of reporting of the financial statements.

$\mathrm{H} 2$ and H02 Hypothesis:

$\mathrm{H} 2$ : The role of internal audit does not serve as the starting point in finding irregularities in the financial statements.

H02: The role of internal audit does serve as the starting point in finding irregularities in the financial statements.

Correlations results

\begin{tabular}{|ll|l|l|}
\hline & Methods & Processes \\
\hline AO & Pearson Correlation & 1 & $-.833^{*}$ \\
& Sig. (2-tailed) & & .002 \\
& $\mathrm{~N}$ & 10 & 10 \\
\hline EFFS & Pearson Correlation & $-.833^{*}$ & 1 \\
& Sig. (2-tailed) & .002 & 10 \\
\hline & $N$ & 10 & \\
\hline
\end{tabular}

*. Correlation is significant at the 0.05 level (2-tailed).

AO - Auditors opininon

\section{EFFS - Erros, frauds in financial stastements}

The hypothesis on the role as the process (independent variable) and starting point in finding the irregularities is linked to errors and fraud during the process (dependent variable) have been tested by the correlation test. According to the table the ruslts show that: the value $r s=0.833$ and $p=0.002$, indicating that there is a strong correlation $(p$-value $<0.05)$. Consequently, hypothesis $\mathrm{H} 2$ is accepted and the alternative hypothesis $\mathrm{H} 02$ is rejected. Therefore it should be noted that: The role of internal audit as a starting point affects the findings of irregularities in the financial statements.

\section{Conclusion}

Public sector organizations are very complex and spend huge amounts of public funds in order to provide their core services to citizens. The complexity of public enterprises makes impossible to senior managers to personally check whether the 
organization is effectively operating. In this context, internal audit function in accordance with the law

is essential to ensure that the organization is functioning effectively. Internal audit establishes opportunities for improving management control, skills and reputation unit. It should be noted that the sources of information helps the auditor to identify management concerns and risks for which was not aware. It should also be emphasized that the issues related to the quality of internal audit have been the focus of many debates all over the world, internal audit has been recognized as one of the controlling mechanisms that has the ability to monitor opportunistic and selfish individuals and therefore is directly related to the quality of financial reporting and in accordance with international accounting standards. Unfortunately, although Kosovo's public companies have their independence they still rely on the board of directors and the audit committee for the financial statements. The main purpose of this study was to establish whether internal audit affects the detection of anomalies and fraud in public financial statements in Kosovo. To realize this purpose we have prepared a questionnaire which we have distributed to public enterprises in Kosovo. From these results we can conclude that the role of internal audit can serve as the starting point for discovery of fraud and error, although there is a negative relation between errors and fraud and financial reporting.

Through our study by analyzing primary and secondary data described above in the paper, we proved that $\mathrm{H} 1$ is not accepted but accepted the alternative hypothesis $\mathrm{H} 01$ indicating that the role of internal audit influences the reliability of financial statements. Also the $\mathrm{H} 2$ hypothesis is not accepted but $\mathrm{HO} 2$ alternative hypothesis was accepted emphasizing that the role of internal audit as a starting point affects the findings of irregularities in financial statements. The vision of internal audit is to add value to public sector organizations in Kosovo providing beneficial, rational and effective use of public funds.

\section{References}

[1] Agarwal, G. K. and Medury, Y. (2014). "Internal Auditor as Accounting Fraud Buster" The IUP journal of accounting research \& audit practices, Vol 13. pp. 7-13.

[2] Alleyne, P. and Howard, M. (2005). An exploratory study of auditors'responsibility for fraud detection in Barbados. Department of Management Studies, Faculty of Social Sciences,

[3] Ayagre, P (2014). "The adoption of risk based internal auditing in developing countries: The case of Ghanian companies." European Journals of Accounting Auditing and Finance Research Vol. 2,No. 7, pp. 52-65

[4] Brady, G. R. and Lowe, J. D. (2003). "The New Role of the Internal Auditor: Implications for Internal Auditor Objectivity." International Journal of Accounting, Vol. 4, No. 2, pp. 169-176.

[5] Chen, J. and Douglas, C. and Hou, W. and Edward, L. (2013). " Executive integrity, audit

[6] Chun, C (1997). "On the functions and objectives of internal audit and their underlying

[7] conditions". Managerial Auditing Journal Volume 12, Issue 4/5.

[8] conservatism: evidence from China. Contemporary Accounting Research 29 (1), 57-93.

[9] Department of Accountancy, John Carrol University,Clevelent, Ohio, USA.

[10] Epstein M and Geiger M (1994), "Investor Views of Audit Assurance: Recent Evidence of the

[11] Expectation Gap", Journal of Accountancy, Vol. 178, No. 5, pp. 60-66.

[12] Firth, M., Fung, P., Rui, O., 2007. Ownership, two-tier board structure, and the informativeness

[13] Firth, M., Mo, P., Wong, R., 2012. Auditors' organizational form, legal liability, and reporting

[14] http://www. issai. org/media/12955/issai_400_e. pdf

[15] http://www. oag-rks. org/repository/docs/RaportiVjetorAuditimit2013_Shqip_272851.Pdf

[16] Internal Auditors Could Make External Audits More Efficient,

[17] internal control weaknesses. Journal of Accounting and Public Policy 26 (2007) 300-327. 
[18] ISSAI 400. Reporting standards in Government Auditing. INTOSAI General Secretariat - RECHNUNGSHOF. A-1033 VIENNA AUSTRIA.

[19] Lomas, R. (2011). Masterin your business dissertation. Routledge, Taylor and Francis Group,

[20] London.

[21] McCullough, D. (2004). Quantitative vs. Qualitative Marketing Research.

[22] MEF (2011). "Diracaku i Auditimit të Brendshëm". Procesi i Auditimit. Ministria e Financave,

[23] Ministry of Finance of Kosovo, "Best practiced of Audit Comitee", https://mf. rks-gov. net/sqal/DEPARTAMENTET/Departamenti-Qendror-Harmonizues/Rregullat-mbi-auditimin-e-brendshem

[24] Nagy, A. L. and Cenker, W. J. (2002). An assessment of the newly defined internal audit function.

[25] of earnings - evidence from China. Journal of Accounting and Public Policy 26, 463-496.

[26] opinion, and fraud in Chinese listed firms". Emerging Markets Review 15 (2013) 72-91.

[27] Republika e Kosovës.

[28] Sekaran, U. (2003). Research Methods for Business: A Skill Building Approach., 4th ed., United

[29] Snider, L. (2000). The sociology of corporate crime: An obituary: (Or whose knowledge claims have legs?). Theoretical Criminology, 4, 169-206.

[30] States, John Wiley \& Sons Inc.

[31] University of the West Indies, Barbados, West Indies.

[32] Zhou, N. and Zhou, J. and Zhang, Y (2007). Audit committee quality, auditor independence, and 